\title{
Selective laser trabeculoplasty as an initial treatment option for open-angle glaucoma
}

\section{Trabeculoplastia seletiva como opção terapêutica inicial para o tratamento do glaucoma de ângulo aberto}

\author{
Ana lúcia Freitas ${ }^{1}$, Michele Ushida² ${ }^{2}$, Izabela Almeida ${ }^{2}$, Diego T. Dias ${ }^{2}$, Syril Dorairaj ${ }^{3}$, Fábio Nishimura Kanadani ${ }^{1}$, Tiago Santos Prata $2,4,5$
}

\begin{abstract}
Although eye drops are frequently used as an initial treatment option for open angle glaucoma (OAG), side effects, and poor adherence, among others, may compromise treatment efficacy. In this scenario, laser trabeculoplasty is an interesting therapeutic option for open angle glaucoma cases. Commonly used for many years as a last alternative prior to glaucoma incisional surgery, laser trabeculoplasty has been changing its indication after the advent of selective laser trabeculoplasty (SLT). In the current review, we critically evaluated the published data regarding the use of laser trabeculoplasty as a first treatment option for open angle glaucoma patients. Studies using SLT as a first-line treatment have encouraging findings. One-year efficacy results are comparable to those obtained with prostaglandin analogues, with a good safety profile. Although the laser's effect is known to be transitory, recent data suggest it can be successfully repeated in cases with good response to the first SLT treatment.
\end{abstract}

Keywords: Glaucoma, open-angle/surgery; Trabeculectomy/methods; Lasers; Intraocular pressure

\section{RESUMO}

Embora a terapia tópica seja frequentemente usada como primeira opção para o tratamento inicial do glaucoma de ângulo aberto (GAA), efeitos colaterais, baixa adesão, entre outros fatores podem comprometer a eficácia do tratamento. Nesse cenário, a trabeculoplastia a laser surge como uma opção terapêutica interessante. Comumente usada como última alternativa antes da cirurgia antiglaucomatosa incisional por muitos anos, a trabeculoplastia a laser tem sido indicada cada vez mais cedo com o advento da trabeculoplastia seletiva a laser (SLT). Nessa revisão, nós avaliamos criticamente as publicações sobre trabeculoplastia a laser como primeira opção para glaucoma de ângulo aberto. Os estudos de SLT como primeira opção terapêutica têm apresentado dados animadores. Os resultados de um ano de acompanhamento mostram eficácia semelhante àquela obtida com análogos de prostaglandinas. Embora o efeito do laser seja transitório, estudos recentes sugerem que o procedimento pode ser repetido com sucesso nos casos que tiveram boa resposta ao primeiro tratamento com SLT.

Descritores: Glaucoma de ângulo aberto/cirurgia; Trabeculectomia/métodos; Lasers; Pressão intraocular

\section{INTRODUCTION}

Glaucoma is an optic neuropathy characterized by progressive structural and functional damage. Intraocular pressure (IOP) is the most important known risk factor for disease development and progression and until now the only modifiable one ${ }^{(1,2)}$. That said, effective IOP reduction is the primary goal when it comes to glaucoma treatment ${ }^{(3)}$.

When it comes to treatment options for IOP reduction, we have three main categories: topical medication, laser surgery, and incisional surgery. Topical hypotensive medications are often used as a first-line treatment option, while incisional surgery is generally used when topical and laser treatments were not effective in achieving the target IOP. Although usually safe and effective, side effects from eye drops may occur, which can be local (e.g., conjunctival injection of prostaglandin analogues)(4) or systemic (e.g., cardiorespiratory effects of beta-blockers) ${ }^{(5)}$. Furthermore, persistence and adherence studies on glaucoma show multiple barriers to an adequate treatment regimen with topical medication ${ }^{(6)}$. Forgetfulness, medication cost, difficulty to instill eye drops, and patient's misbelief that glaucoma is a blinding disease are frequently reported ${ }^{(6)}$. As a result, self-reported treatment adherence rates are poor (ranging from 30 to $80 \%)^{(7,8)}$, and many patients interrupt their newly prescribed medications in the first year of treatment ${ }^{(9,10)}$. Therefore, an initial therapeutic alternative that minimizes ocular side effects and compliance issues could be very useful in clinical practice.

In this context, laser trabeculoplasty rises as an interesting therapeutic option for open-angle glaucoma (OAG) cases, not relying on patient compliance. Argon laser trabeculoplasty (ALT) was first described in 1979 (Table 1)(11). The laser uses a blue-green (488 and $514 \mathrm{~nm}$ ) continuous wave argon laser with a $50 \mu \mathrm{m}$ spot diameter and makes a disruption of the trabecular meshwork ${ }^{(12,13)}$. In 1995, selective laser trabeculoplasty (SLT) was described. This melanin-target tissue sparing procedure uses a green (532 nm), Q-switched, frequencydoubled Nd:YAG laser ${ }^{(13)}$. It is important to emphasize that ordinary YAG laser devices, commonly used for iridotomy or capsulotomy, cannot be used to perform SLT.

Laser trabeculoplasty was initially described as an adjunctive treatment in eyes under topical hypotensive medications, often performed as a last alternative prior to incisional surgery in cases of uncontrolled disease ${ }^{(14)}$. With the advent of SLT, there was a shift in the focus of most clinical studies related to laser trabeculoplasty ${ }^{(12,15)}$. Looking carefully at the most recent publications, one can note that SLT has been evaluated as a first-line treatment option for IOP-lowering in OAG patients without topical medication and less severe damage, with quite encouraging results ${ }^{(16,17)}$.

Department of Ophthalmology, Hospital Universitário de Ciências Médicas, Belo Horizonte, MG, Brazil. Glaucoma Unit, Hospital Medicina dos Olhos, Osasco, SP, Brazil.

Glaucoma Unit, Hospital Medicina dos Olhos, Osasco, SP, Brazil.
Glaucoma Unit, Department of Ophthalmology, Mayo Clinic, Jacksonville, FL, USA.

4 Glaucoma Service, Department of Ophthalmology and Visual Science, Escola Paulista de Medicina

(EPM), Universidade Federal de São Paulo (UNIFESP), São Paulo, SP, Brazil.

Glaucoma Service, Department of Ophthalmology, Hospital Oftalmológico de Sorocaba, Sorocaba,

$\mathrm{SP}$, Brazil.

Funding: No specific financial support was available for this study.

Disclosure of potential conflicts of interest: None of the authors have any potential conflict of interest to disclose.

Corresponding address: Tiago S. Prata. Rua Dr. Jose Rodrigues Alves Sobrinho, 125 - São Paulo, SP - 05466-040 - Brazil - E-mail: t.prata0807@gmail.com 
In the current review, we critically evaluated the published data regarding the use of laser trabeculoplasty as a first treatment option for OAG patients. We conducted a PubMed search on March 19, 2016 using the following keywords: "laser trabeculoplasty", "open-angle glaucoma", and "treatment". All types of studies were considered for a first analysis. Only case-reports were excluded. Meeting abstracts were considered if presenting relevant and new data. Studies were then selected based on clinical relevance and contribution to the main focus of this review article. As most studies comparing ALT with SLT results were conducted in glaucoma patients under clinical treatment, we could not restrict our search criteria to studies using laser as first treatment option only. Therefore, we also included data from studies in patients already being treated by medication.

\section{TOPICS}

\section{LASER TRABECULOPLASTY AS INITIAL TREATMENT FOR OPEN ANGLE GLAUCOMA}

The idea of using laser trabeculoplasty as the first treatment option for glaucoma is not recent nor restrict to SLT. The Glaucoma Laser Trial (GLT) was a multicenter study that evaluated the efficacy and safety of ALT as the primary therapy for glaucoma. In that study, patients with OAG were randomly assigned for initial treatment with ALT in one eye versus topical medication in the fellow eye. The main results showed that initial treatment with ALT was associated with a greater IOP reduction (mean difference of $1.2 \mathrm{mmHg}$ ) and better visual field outcomes (mean difference of $0.6 \mathrm{~dB}$ ) than topical treatment with timolol maleate. Additionally, ALT was at least as effective as timolol regarding stability of optic disc status over seven years ${ }^{(14)}$. It is important to note that when GLT was carried out, neither prostaglandin analogs (PGA) nor SLT were available, thus limiting a straight comparison with more recent studies data ${ }^{(18)}$.

There are scant data in the literature comparing ALT vs SLT as the initial treatment options for OAG cases. In a relatively recent study by Gandolfi et al. ${ }^{(19)}$, the authors reported that low power $360^{\circ}$ SLT (repeated every year) was more effective than conventional ALT in achieving adequate IOP control in cases of ocular hypertension. On the other hand, most studies comparing ALT vs SLT for OAG (but not as a first treatment option) found similar success rates between the two laser modalities ${ }^{(20-22)}$. However, when it comes to safety, the development of peripheral anterior synechiae seems to be a more frequent complication following ALT (incidence ranging between $12 \%$ and $43 \%$ in previous studies) than SLT (rarely reported) ${ }^{(23,24)}$. This procedure-related complication is influenced by technique and laser burns position (higher risk when laser is applied too posteriorly). Moreover, we believe that the ease of application (outcomes of physicians in training are comparable to those of glaucoma specialists) ${ }^{(25)}$ and the possibility of repeating the procedure with relatively good success rates (in cases with good response to the first SLT treatment) ${ }^{(20,26)}$ are two important advantages of SLT over ALT treatment. These factors have certainly contributed to the shift towards SLT use in the past decade and might explain the reason why ALT has not taken its place as a first line therapy.

\section{Selective Laser trabeculoplasty as initial treatment for OPEN ANGLE GLAUCOMA \\ Efficacy (IOP reduction)}

In most studies, SLT has been investigated as a second-line treatment option for $O A G$, being performed only after inappropriate response or intolerance to topical medication as an attempt to delay incisional surgery ${ }^{(27)}$. As a result, there are few studies evaluating SLT as first treatment option. It is important to note that because the SLT effect is transitory, most of these studies are short-term (one to three years of follow-up). As PGAs are the first line clinical treatment to OAG, most studies compared SLT with PGA results in terms of IOP reduction. Looking carefully at safety and efficacy outcomes of these studies, we believe there is growing evidence that SLT can be used as a primary treatment for IOP-control in OAG cases $^{(17,28-33)}$. Table 2 provides a summary of the main results of these studies.

Table 1. Comparison of the different features of argon laser trabeculoplasty (ALT) and selective laser trabeculoplasty (SLT)

\begin{tabular}{lcc}
\hline & ALT & SLT \\
\hline Described in & 1979 & 1995 \\
Laser type & Argon laser & Q-switched, frequency-doubled Nd:YAG laser \\
Laser wavelength & 488 and $514 \mathrm{~nm}$ (blue-green) & $532 \mathrm{~nm}$ (green) \\
Spot diameter & $50 \mu \mathrm{m}$ & $400 \mu \mathrm{m}$ \\
Main action mechanisms & Disruption of the trabecular meshwork & Melanin-target tissue sparing \\
\hline
\end{tabular}

Table 2. Studies of selective laser trabeculoplasty as the first treatment option for open-angle glaucoma and ocular hypertension

\begin{tabular}{|c|c|c|}
\hline Study & Design & Key findings \\
\hline Katz et al., (2012) & $\begin{array}{l}\text { SLT versus PGA } \\
\text { Total of } 127 \text { eyes }\end{array}$ & $\begin{array}{l}\text { Mean IOP reduction of } 25.7 \% \\
\text { Equally efficacy } \\
\text { FU: } 12 \text { months }\end{array}$ \\
\hline Shazly et al., $(2010)^{31}$ & $\begin{array}{l}\text { SLT-POAG and PXFG } \\
\text { Total of } 37 \text { eyes }\end{array}$ & $\begin{array}{c}\text { Mean IOP reduction of } 23 \% \\
\text { FU: } 49 \text { months }\end{array}$ \\
\hline Mahdy $(2008)^{29}$ & $\begin{array}{l}\text { SLT-OAG and OHT } \\
\text { Total of } 35 \text { eyes }\end{array}$ & $\begin{array}{c}\text { Mean IOP reduction of } 27.8 \% \\
\text { FU: } 12 \text { months }\end{array}$ \\
\hline Mcllraith et al., (2006) $)^{17}$ & $\begin{array}{l}\text { SLT versus PGA } \\
\text { Total of } 100 \text { eyes }\end{array}$ & $\begin{array}{l}\text { Mean IOP reduction of } 31 \% \\
\text { Equally efficacy } \\
\text { FU: } 12 \text { months }\end{array}$ \\
\hline Nagar et al., (2005) ${ }^{18 *}$ & $\begin{array}{l}\text { SLT versus PGA } \\
\text { Total of } 167 \text { eyes }\end{array}$ & $\begin{array}{c}\text { In } 360^{\circ} \mathrm{SLT}, 82 \% \text { of eyes achieved a }>20 \% \text { IOP reduction } \\
\text { Equally efficacy }\left(360^{\circ} \mathrm{SLT} \text { vs PGA) }\right. \\
\text { FU: } 12 \text { months }\end{array}$ \\
\hline Melamed et al., $(2003)^{33}$ & $\begin{array}{l}\text { SLT-OAG and OHT } \\
\text { Total of } 45 \text { eyes }\end{array}$ & $\begin{array}{c}\text { Mean IOP reduction of } 30 \% \\
\text { FU: } 18 \text { months }\end{array}$ \\
\hline
\end{tabular}


At this point, we believe it is important to briefly discuss the main aspects of each study. When evaluating patients with OAG or ocular hypertension $(\mathrm{OHT})$ treated with SLT, Melamed et al. ${ }^{(33)}$ observed a $\geq 19.6 \%$ IOP reduction in $89 \%$ of the patients, while Mahdy ${ }^{(29)}$ found an IOP-reduction $\geq 25 \%$ in $77.1 \%$ of the cases. Overall, in an attempt to summarize IOP data from the available studies, we found that average absolute IOP-reduction following SLT as first treatment ranges from 3 to $8 \mathrm{mmHg}$ (percentage IOP reduction: $20 \%$ to 38\%) ${ }^{(17,18,29,31,33,34)}$.

Other studies compared SLT versus PGA as a primary therapy, with similar efficacy between the two treatment modalities ${ }^{(16-18)}$. When the extension of the laser was considered, PGA showed better results than $90^{\circ}$ and $180^{\circ} \mathrm{SLT}$, but not $360^{\circ}(18)$. The efficacy of SLT was also evaluated in OAG eyes previously treated with glaucoma medication (monotherapy) $)^{(34)}$. After a 30-day medication washout, SLT reduced IOP significantly, and IOP remained stable without medical therapy for 12 months ${ }^{(34)}$. In addition, another study also evaluated SLT results after topical medication washout, and SLT $360^{\circ}$ was effective [mean IOP reduction of $2.9 \mathrm{mmHg}(40 \%)$ at 3 months and $2.1 \mathrm{mmHg}(29.2 \%)$ at 6 months after the laser) ${ }^{(35)}$. Besides that, another study that included eyes with pseudoexfoliative glaucoma (XFG) and primary openangle glaucoma (POAG) revealed that SLT was effective as a primary treatment in both groups ${ }^{(31)}$.

\section{Safety, duration, and repeatability}

In general, SLT is considered a safe procedure ${ }^{(36)}$. Serious complications are rare, but conjunctival redness and injection ${ }^{(33,37)}$, transient IOP-increase ${ }^{(33,38,39)}$, and mild anterior chamber reaction ${ }^{(37,38,40)}$ are issues that the ophthalmologist and the patient should be aware of. Special attention must be given to sustained IOP increase ${ }^{(41)}$, particularly in higher risk patients, such as individuals with highly pigmented trabecular meshwork, multiple topical medications, and previous ALT treatment ${ }^{(42)}$. Although loss of corneal endothelial cells has been reported, it does not seem to be permanent, as recovery was observed after one month of the procedure ${ }^{(43)}$. Additionally, anterior chamber volume and central corneal thickness decrease after SLT, retuning back to pre-SLT values after three months of the laser procedure ${ }^{(44)}$.

It is well established that the IOP-lowering effect of SLT decreases over time ${ }^{(38)}$. Although it is usually attributed to the transitory effectiveness of the procedure ${ }^{(21,38)}$, the progressive trabecular meshwork dysfunction presented by glaucomatous patients along the years should also be considered ${ }^{(45)}$. In this context, the possibility of repeating the laser procedure in eyes that lost IOP control over time became an important point to be investigated. Looking close at the more recent literature, one can note several studies showing that SLT can be repeated with similar efficacy when compared to the first SLT treatment. In these studies, POAG patients presented a significant IOP reduction at $1^{(46)}, 4^{(47)}, 6^{(46)}, 12^{(19,48)}, 15^{(46)}$, and 24 months after repeating $\mathrm{SLT}^{(26,49)}$. Corroborating these findings, Gandolfi and Ungaro demonstrated that repeated low power SLT as initial treatment postponed the initiation of medical therapy by a mean time of 6.2 years in patients with $\mathrm{OHT}^{(19)}$.

\section{Success predictors of selective laser trabeculoplasty}

As mentioned above, SLT does not work for everyone, as approximately one quarter of the patients do not achieve a significant IOP reduction ${ }^{(50)}$. Therefore, the knowledge of success predictors is important for a proper indication and to estimate treatment outcomes. Some success predictors are well established. For instance, better results are usually observed in patients with POAG $(33,37,51-56)$, pseudoexfoliative glaucoma ${ }^{(31,40,57,58)}$, and higher baseline $\operatorname{IOP}^{(40,41,46,47)}$. A few isolated studies observed better results in eyes with thinner corneas ${ }^{(59)}$, with earlier disease stage ${ }^{(60)}$, and with higher refractive errors ${ }^{(52)}$. Conversely, the use of PGA before laser was associated with a decreased IOP-lowering response ${ }^{(61)}$, and SLT treatment had limited results in eyes with $O A G$ receiving maximal-tolerable medical therapy ${ }^{(50,62)}$. Other factors remain controversial, such as iridocorneal angle pigmentation ${ }^{(63,64)}$ and advanced age ${ }^{(57,61)}$. While some studies found a positive correlation between these factors and success rates, others did not. Regarding laser parameters itself, although good results have been recently reported with low power SLT (0.4 mJ per shot; repeated annually)(19), most studies have suggested better outcomes with higher power settings (energy per shot), more extensive laser treatment (360 degree), and greater number of shots ${ }^{(18,25,65,66)}$.

There is also a strong correlation between SLT outcomes when we consider both eyes from the same patient ${ }^{(67)}$. Shazly and Latina, evaluating eyes with OAG and OHT, found that in patients with SLT failure in the first treated eye, success odds in the fellow eye were less than $35 \%{ }^{(67)}$. Considering those with good response in the first treated eye, success rates of the fellow eye varied between $80 \%$ and $100 \%$ in two different studies ${ }^{(68)}$. In this context, it seems reasonable to perform SLT in one eye at a time. Not only because success odds of the second eye are remote in cases of failure of the first treated eye (and therefore the second eye should not be indicated in such cases), but also because the IOP values of the fellow untreated eye can be used to adjust SLT outcomes of the first treated eye (mitigating the influence of inter-visits IOP fluctuation and reducing the influence of regression to the mean).

\section{COMMENT}

During the course of OAG, patients will often need one or more medications to maintain IOP control and prevent progression of the disease. Ocular and systemic side effects of topical medications, forgetfulness, difficulties in handling the bottle and instill eye drops properly, and consequently poor compliance with the proposed medical regimen are important issues for clinicians when starting a therapy that will last a lifetime ${ }^{(6,8)}$. Moreover, growing concern exists with drug-related chronic ocular surface inflammation, which may have a negative impact on success of a future filtration surgery ${ }^{(69)}$. With this in mind, we believe it is reasonable to consider alternative treatments, such as laser therapy, as first-line treatment options (17,28,29). $^{(12)}$ SLT has a good safety profile, does not rely on patient compliance, and has shown to be at least as effective as topical medications in lowering IOP as an initial treatment (for at least one year) ${ }^{(70-72)}$ and can be repeated when IOP control is lost over time ${ }^{(19,46-48)}$, possibly allowing patients to remain free of topical medication for years ${ }^{(73,74)}$. In a chronic disease such as OAG, time is always a key parameter. We believe that SLT can be a way to buy it. Additionally, if this strategy does not work, topical medications can be promptly started. Nevertheless, it should be emphasized that studies are needed to evaluate whether SLT treatment would affect the efficacy of topical hypotensive medications. All these things considered, SLT seems to be a reasonable, but still underused, form of initial treatment for patients with $\mathrm{OAG}$ and $\mathrm{OHT}$.

\section{REFERENCES}

1. Weinreb RN, Khaw PT. Primary open-angle glaucoma. Lancet. 2004;363(9422):1711-20. Comment in: Lancet. 2004;364(9442):1311-2.

2. Comparison of glaucomatous progression between untreated patients with normal-tension glaucoma and patients with therapeutically reduced intraocular pressures. Collaborative Normal-Tension Glaucoma Study Group. Am J Ophthalmol. 1998;126(4):487-97. Erratum in: Am J Ophthalmol. 1999;127(1):120.

3. Heijl A, Leske MC, Bengtsson B, Hyman L, Bengtsson B, Hussein M. Early Manifest Glaucoma Trial Group. Reduction of intraocular pressure and glaucoma progression: results from the Early Manifest Glaucoma Trial. Arch Ophthalmol. 2002;120(10):1268-79. Comment in: Arch Opthalmol. 2002;120(10):1371-2; JAMA. 2002;288(20):2607-8; Optom Vis Sci. 2002;79(12):741-2

4. Alm A, Grierson I, Shields MB. Side effects associated with prostaglandin analog therapy. Surv Ophthalmol. 2008;53 Suppl1(6):S93-S105.

5. Lama PJ. Systemic adverse effects of beta-adrenergic blockers: an evidence-based assessment. Am J Ophthalmol. 2002;134(5):749-60.

6. Newman-Casey PA, Robin AL, Blachley T, Farris K, Heisler M, Resnicow K, et al. The most common barriers to glaucoma medication adherence: a cross-sectional survey. Ophthalmology. 2015;122(7):1308-16. doi:10.1016/j.ophtha.2015.03.026. 
7. Olthoff CM, Schouten JS, van de Borne BW, Webers CA. Noncompliance with ocular hypotensive treatment in patients with glaucoma or ocular hypertension an evidence-based review. Ophthalmology. 2005;112(6):953-61.

8. Schwartz GF, Quigley HA. Adherence and persistence with glaucoma therapy. Surv Ophthalmol. 2008;53 Suppl1:S57-S68.doi:10.1016/j.survophthal.2008.08.002.

9. Dasgupta S, Oates V, Bookhart BK, Vaziri B, Schwartz GF, Mozaffari E. Population-based persistency rates for topical glaucoma medications measured with pharmacy claims data. Am J Manag Care. 2002;8(10 Suppl):S255-S261.

10. Fiscella RG. Persistency with glaucoma medication. Am J Ophthalmol. 2004;138(6): 1093-4-author reply1094. Comment in: Am J Ophthalmol. 2004;137(1 Suppl):S1-2.

11. Wise JB, Witter SL. Argon laser therapy for open-angle glaucoma. A pilot study. Arch Ophthalmol. 1979;97(2):319-22.

12. Kramer TR, Noecker RJ. Comparison of the morphologic changes after selective laser trabeculoplasty and argon laser trabeculoplasty in human eye bank eyes. Ophthalmology. 2001;108(4):773-9.

13. Kagan DB, Gorfinkel NS, Hutnik CM. Mechanisms of selective laser trabeculoplasty: a review. Clin Experiment Ophthalmol. 2014;42(7):675-81. doi:10.1111/ceo.12281.

14. The Glaucoma Laser Trial (GLT) and glaucoma laser trial follow-up study: 7. Results. Glaucoma Laser Trial Research Group. Am J Ophthalmol. 1995;120(6):718-31.

15. Ekici F, Waisbourd M, Katz LJ. Current and future of laser therapy in the management of glaucoma. Open Ophthalmol J. 2016;10:56-67. doi:10.2174/1874364101610010056.

16. Katz LJ, Steinmann WC, Kabir A, Molineaux J, Wizov SS, Marcellino G. SLT/Med Study Group. Selective laser trabeculoplasty versus medical therapy as initial treatment of glaucoma: a prospective, randomized trial. J Glaucoma. 2012;21(7):460-8. doi: 10.1097/IJG.0b013e318218287f.

17. Mcllraith I, Strasfeld M, Colev G, Hutnik CML. Selective laser trabeculoplasty as initial and adjunctive treatment for open-angle glaucoma. J Glaucoma. 2006;15(2):124-30.

18. Nagar M, Ogunyomade A, O'Brart DP, Howes F, Marshall J. A randomised, prospective study comparing selective laser trabeculoplasty with latanoprost for the control of intraocular pressure in ocular hypertension and open angle glaucoma. $\mathrm{Br} J$ Ophthalmol. 2005;89(11):1413-7. doi: 10.1136/bjo.2004.052795

19. Gandolfi SA, Ungaro N. Low power selective laser trabecuoplasty (SLT) repeated yearly as primary treatment in ocular hypertension: long term comparison with conventional SLT and ALT. Invest Ophthalmol Vis Sci. 2014;55(13):818.

20. Wang W, He M, Zhou M, Zhang X. Selective laser trabeculoplasty versus argon laser trabeculoplasty in patients with open-angle glaucoma: a systematic review and meta-analysis. PLoS One. 2013;8(12):e84270. doi:10.1371/journal.pone.0084270.

21. Juzych MS, Chopra V, Banitt MR, Hughes BA, Kim C, Goulas MT, et al. Comparison of long-term outcomes of selective laser trabeculoplasty versus argon laser trabeculoplasty in open-angle glaucoma. Ophthalmology. 2004:111(10):1853-9.

22. Wang H, Cheng JW, Wei RL, Cai JP, Li Y, Ma XY. Meta-analysis of selective laser trabeculoplasty with argon laser trabeculoplasty in the treatment of open-angle glaucoma. Can J Ophthalmol. 2013:48(3):186-92. doi:10.1016/j.jcjo.2013.01.001.

23. Rouhiainen HJ, Teräsvirta ME, Tuovinen EJ. Peripheral anterior synechiae formation after trabeculoplasty. Arch Ophthalmol. 1988;106(2):189-91.

24. Traverso CE, Greenidge KC, Spaeth GL. Formation of peripheral anterior synechiae following argon laser trabeculoplasty. A prospective study to determine relationship to position of laser burns. Arch Ophthalmol. 1984;102(6):861-3.

25. Greninger DA, Lowry EA, Porco TC, Naseri A, Stamper RL, Han Y. Resident-performed selective laser trabeculoplasty in patients with open-angle glaucoma. JAMA Ophthalmol. 2014;132(4):403-8. doi:10.1001/jamaophthalmol.2013.7651.

26. Polat J, Grantham L, Mitchell K, Realini T. Repeatability of selective laser trabeculoplasty. Br J Ophthalmol. February 2016;100(10):1437-41.

27. Gracner T. Intraocular pressure reduction after selective laser trabeculoplasty in primary open angle glaucoma. Coll Antropol. 2001;25 Suppl:111-5.

28. Waisbourd M, Katz LJ. Selective laser trabeculoplasty as a first-line therapy: a review. Can J Ophthalmol. 2014:49(6):519-22. doi:10.1016/j.jcjo.2014.10.003.

29. Mahdy MA. Efficacy and safety of selective laser trabeculoplasty as a primary procedure for controlling intraocular pressure in primary open angle glaucoma and ocular hypertensive patients. Sultan Qaboos Univ Med J. 2008;8(1):53-8.

30. Latina MA, Tumbocon JA. Selective laser trabeculoplasty: a new treatment option for open angle glaucoma. Curr Opin Ophthalmol. 2002;13(2):94-6.

31. Shazly TA, Smith J, Latina MA. Long-term safety and efficacy of selective laser trabeculoplasty as primary therapy for the treatment of pseudoexfoliation glaucoma compared with primary open-angle glaucoma. Clin Ophthalmol. 2010:5:5-10.

32. Peng W, Zhong X, Yu M. [Meta-analysis of randomized controlled trials comparing selective laser trabeculoplasty with prostaglandin analogue in the primary treatment of open-angle glaucoma or ocular hypertention]. Zhonghua Yan Ke Za Zhi. 2014;50(5):343-8. Chinese.

33. Melamed S, Ben Simon GJ, Levkovitch-Verbin H. Selective laser trabeculoplasty as primary treatment for open-angle glaucoma: a prospective, nonrandomized pilot study. Arch Ophthalmol. 2003;121(7):957-60. doi:10.1001/archopht.121.7.957

34. Realini T. Selective laser trabeculoplasty for the management of open-angle glaucoma in St. Lucia. JAMA Ophthalmol. 2013;131(3):321-7. doi:10.1001/jamaophthalmol. 2013.1706.

35. Kóthy P, Tóth M, Holló G. Influence of selective laser trabeculoplasty on 24-hour diurnal intraocular pressure fluctuation in primary open-angle glaucoma: a pilot study. Ophthalmic Surg Lasers Imaging. 2010;41(3):342-7. doi:10.3928/15428877-20100430-08.
36. Ayala M, Landau Högbeck I, Chen E. Inflammation assessment after selective laser trabeculoplasty (SLT) treatment. Acta Ophthalmol. 2011;89(4):e306-e309. doi:10.1111/j.1755-3768.2010.02029.x.

37. Thatsnarong D, Ngamchittiampai C, Phoksunthorn T. One year results of selective laser trabeculoplasty in the treatment of primary open angle glaucoma. J Med Assoc Thai. 2010;93(2):211-4.

38. Cvenkel B. One-year follow-up of selective laser trabeculoplasty in open-angle glaucoma. Ophthalmologica. 2004;218(1):20-5. doi:10.1159/000074562.

39. Song J. Complications of selective laser trabeculoplasty: a review. Clin Ophthalmol. 2016:10:137-43. doi:10.2147/OPTH.S84996.

40. Kara N, Altan C, Yuksel K, Tetikoglu M. Comparison of the efficacy and safety of selective laser trabeculoplasty in cases with primary open-angle glaucoma and pseudoexfoliative glaucoma. Kaohsiung J Med Sci. 2013;29(9):500-4. doi:10.1016/j. kjms.2013.01.005

41. Almeida ED, Pinto LM, Fernandes RA, Prata TS. Pattern of intraocular pressure reduction following laser trabeculoplasty in open-angle glaucoma patients: comparison between selective and nonselective treatment. Clin Ophthalmol. 2011;5:933-6. doi:10.2147/OPTH.S21759

42. Harasymowycz PJ, Papamatheakis DG, Latina M, De Leon M, Lesk MR, Damji KF. Selective laser trabeculoplasty (SLT) complicated by intraocular pressure elevation in eyes with heavily pigmented trabecular meshworks. Am J Ophthalmol. 2005;139(6): 1110-3. doi:10.1016/j.ajo.2004.11.038.

43. Lee JW, Chan JC, Chang RT, Singh K, Liu CC, Gangwani R, et al. Corneal changes after a single session of selective laser trabeculoplasty for open-angle glaucoma. Eye (Lond) 2014:28(1):47-52. doi:10.1038/eye.2013.231.

44. Guven Yilmaz S, Palamar M, Yusifov E, Ates H, Egrilmez S, Yagci A. Effects of primary selective laser trabeculoplasty on anterior segment parameters. Int J Ophthalmol. 2015 8(5):954-9. doi:10.3980/j.issn.2222-3959.2015.05.18

45. Tektas O-Y, Lütjen-Drecoll E. Structural changes of the trabecular meshwork in different kinds of glaucoma. Exp Eye Res. 2009;88(4):769-75. doi:10.1016/j.exer.2008.11.025.

46. Durr GM, Harasymowycz P. The effect of repeat 360-degree selective laser trabeculoplasty on intraocular pressure control in open-angle glaucoma. J Fr Ophtalmol. March 2016:39(3):261-4. doi:10.1016/j.jfo.2015.10.008

47. Avery N, Ang GS, Nicholas S, Wells A. Repeatability of primary selective laser trabeculoplasty in patients with primary open-angle glaucoma. Int Ophthalmol. 2013:33(5):501-6. doi:10.1007/s10792-013-9729-3.

48. Hong BK, Winer JC, Martone JF, Wand M, Altman B, Shields B. Repeat selective lase trabeculoplasty. J Glaucoma. 2009;18(3):180-3. doi:10.1097/JJG.0b013e31817eee0b.

49. Khouri AS, Lari HB, Berezina TL, Maltzman B, Fechtner RD. Long term efficacy of repeat selective laser trabeculoplasty. J Ophthalmic Vis Res. 2014;9(4):444-8. doi: 10.4103/2008-322X.150814.

50. Barretto GC, Biteli LG, Moreno PA, Prata TS. Selective Laser Trabeculoplasty: Predictors of Short-Term Surgical Outcomes in Open-Angle Glaucoma Patients. Invest Ophthalmol Vis Sci. 2011:52(14):2624.

51. Kontić M, Ristić D, Vukosavljević M. Hypotensive effect of selective laser trabeculoplasty in patients with medically uncontrolled primary open-angle glaucoma. Srp Arh Celok Lek. 2014;142(9-10):524-8.

52. Lee JW, Liu CC, Chan JC, Wong RL, Wong IY, Lai JS. Predictors of success in selective laser trabeculoplasty for primary open angle glaucoma in Chinese. Clin Ophthalmol. 2014;8:1787-91. doi:10.2147/OPTH.S69166.

53. Abdelrahman AM, Eltanamly RM. Selective laser trabeculoplasty in Egyptian patients with primary open-angle glaucoma. Middle East Afr J Ophthalmol. 2012;19(3):299-303. doi:10.4103/0974-9233.97930.

54. Weinand FS, Althen F. Long-term clinical results of selective laser trabeculoplasty in the treatment of primary open angle glaucoma. Eur J Ophthalmol. 2006;16(1):100-4.

55. Francis BA, lanchulev T, Schofield JK, Minckler DS. Selective laser trabeculoplasty as a replacement for medical therapy in open-angle glaucoma. Am J Ophthalmol. 2005;140(3):524-5. doi:10.1016/j.ajo.2005.02.047.

56. Chiselita D, Cantemir A, Pantalon AD. Selective laser trabeculoplasty--short term efficacy and safety profile in open angle glaucoma or ocular hypertension treatment. Rom J Ophthalmol. 2015:59(3):148-53.

57. Ayala M, Chen E. Comparison of selective laser trabeculoplasty (SLT) in primary open angle glaucoma and pseudoexfoliation glaucoma. Clin Ophthalmol. 2011;5:1469-73. doi:10.2147/OPTH.S25636

58. Koucheki B, Hashemi H. Selective laser trabeculoplasty in the treatment of open-angle glaucoma. J Glaucoma. 2012;21(1):65-70. doi:10.1097/IJG.0b013e3182027596.

59. Shazly TA, Latina MA, Dagianis JJ, Chitturi S. Effect of central corneal thickness on the long-term outcome of selective laser trabeculoplasty as primary treatment for ocular hypertension and primary open-angle glaucoma. Cornea. 2012;31(8):883-6. doi:10.1097/ICO.0b013e318243f684.

60. Schlote T, Kynigopoulos M. Selective laser trabeculoplasty (SLT): 1-year results in early and advanced open angle glaucoma. Int Ophthalmol. 2016;36(1):55-61. doi:10.1007/ s10792-015-0079-1.

61. Bruen R, Lesk MR, Harasymowycz P. Baseline factors predictive of SLT response: a prospective study. J Ophthalmol. 2012;2012(11):642869-5. doi:10.1155/2012/642869.

62. Miki A, Kawashima R, Usui S, Matsushita K, Nishida K. Treatment outcomes and prognostic factors of selective laser trabeculoplasty for open-angle glaucoma receiving 
maximal-tolerable medical therapy. J Glaucoma. 2016;25(10):78509. doi:10.1097/ JG.0000000000000411.

63. Wasyluk JT, Piekarniak-Woźniak A, Grabska-Liberek I. The hypotensive effect of selective laser trabeculoplasty depending on iridocorneal angle pigmentation in primary open angle glaucoma patients. Arch Med Sci. 2014;10(2):306-8. doi:10.5114/ aoms.2014.42583.

64. Tardif A, Bonnin N, Borel A, Viennet A, Pereira B, Chiambaretta F. [Selective laser trabeculoplasty: results after a first and a second session, overall comparison and results for three indications]. J Fr Ophtalmol. 2014;37(5):353-7. doi:10.1016/j.jfo.2013.08.008. French.

65. Lee JW, Wong MO, Liu CC, Lai JS. Optimal selective laser trabeculoplasty energy for maximal intraocular pressure reduction in open-angle glaucoma. J Glaucoma. 2015; 24(5):e128-e131. doi:10.1097/IJG.0000000000000215.

66. Shibata M, Sugiyama T, Ishida O, Ueki M, Kojima S, Okuda T, et al. Clinical results of selective laser trabeculoplasty in open-angle glaucoma in Japanese eyes: comparison of 180 degree with 360 degree SLT. J Glaucoma. 2012;21(1):17-21. doi:10.1097/ IJG.0b013e3181fc8020

67. Shazly TA, Latina MA. Intraocular pressure response to selective laser trabeculoplasty in the first treated eye vs the fellow eye. Arch Ophthalmol. 2011;129(6):699-702. doi:10.1001/archophthalmol.2011.108

68. Lee JW, Wong MO, Wong RL, Lai JS. Correlation of intraocular pressure between both eyes after bilateral selective laser trabeculoplasty in open-angle glaucoma. J Glaucoma. 2016;25(3):e248-e252 doi:10.1097/JJG.0000000000000274.

69. Baudouin C. Ocular surface and external filtration surgery: mutual relationships. Dev Ophthalmol. 2012;50:64-78. doi:10.1159/000334791.

70. Wong MO, Lee JW, Choy BN, Chan JC, Lai JS. Systematic review and meta-analysis on the efficacy of selective laser trabeculoplasty in open-angle glaucoma. Surv Ophthalmol. 2015;60(1):36-50. doi:10.1016/j.survophthal.2014.06.006.

71. Li X, Wang W, Zhang X. Meta-analysis of selective laser trabeculoplasty versus topical medication in the treatment of open-angle glaucoma. BMC Ophthalmol. 2015; 15(1):107. doi:10.1186/s12886-015-0091-2.

72. McAlinden C. Selective laser trabeculoplasty (SLT) vs other treatment modalities for glaucoma: systematic review. Eye (Lond). 2014;28(3):249-58. doi:10.1038/eye. 2013.267.

73. Nagar M, Luhishi E, Shah N. Intraocular pressure control and fluctuation: the effect of treatment with selective laser trabeculoplasty. Br J Ophthalmol. 2009:93(4):497-501. doi:10.1136/bjo.2008.148510.

74. Prasad N, Murthy S, Dagianis JJ, Latina MA. A comparison of the intervisit intraocular pressure fluctuation after 180 and 360 degrees of selective laser trabeculoplasty (SLT) as a primary therapy in primary open angle glaucoma and ocular hypertension. J Glaucoma. 2009:18(2):157-60. doi:10.1097/IJG.0b013e3181752c97.

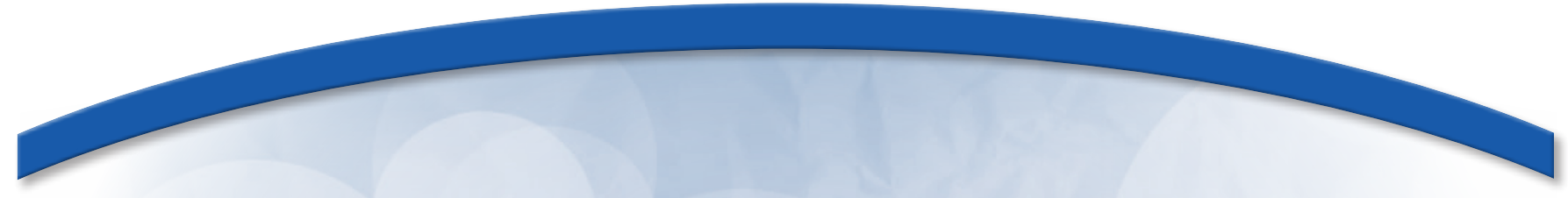

\title{
$24^{\circ}$ Congresso Internacional de Oftalmologia da Santa Casa de São Paulo
}

\author{
21 a 24 de junho de 2017 \\ Clube Hebraica \\ São Paulo - SP
}

Informações:

Site: www.santacasasimposio.com.br

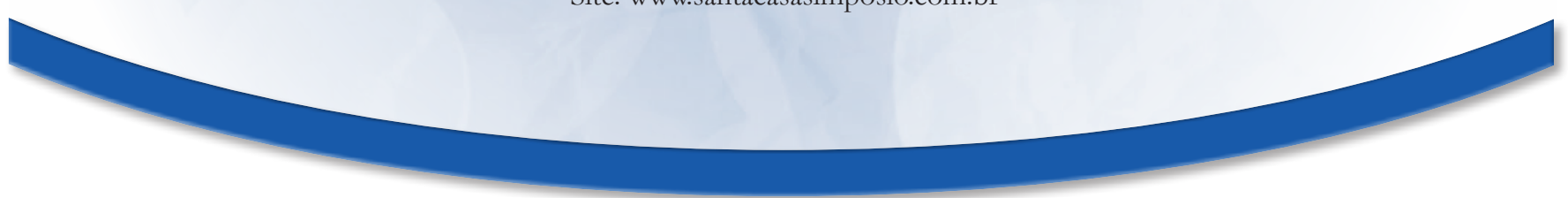

